\title{
Effects of nonstructural carbohydrate concentration in alfalfa on fermentation and microbial protein synthesis in continuous culture ${ }^{1}$
}

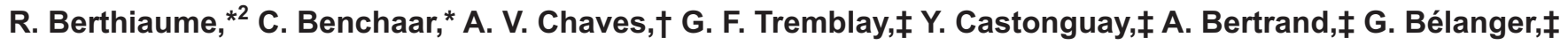 \\ R. Michaud,ł C. Lafrenière, ${ }^{*}$ T. A. McAllister, $†$ and A. F. Brito \\ *Agriculture and Agri-Food Canada, Dairy and Swine Research and Development Centre, Sherbrooke, Québec, Canada J1M $1 Z 3$ \\ †Agriculture and Agri-Food Canada, Lethbridge Research Centre, P.O. Box 3000, Lethbridge, Alberta, Canada T1J 4B1 \\ $\ddagger$ Agriculture and Agri-Food Canada, Soils and Crops Research and Development Centre, Québec, Québec, Canada G1V 2J3 \\ $\S$ Department of Biological Sciences, University of New Hampshire, Durham 03824
}

\begin{abstract}
Insufficient readily fermentable energy combined with extensive degradation of proteins in alfalfa (Medicago sativa L.) may result in poor forage $\mathrm{N}$ utilization by ruminants. Using the inherent genetic variability and differences between harvests, our objective was to compare the effect of contrasting concentrations of nonstructural carbohydrates (NSC) in alfalfa on rumen fermentation and microbial protein synthesis. Individual genotypes of the alfalfa cultivar AC Caribou grown near Québec City, Québec, Canada, were harvested at the vegetative and early flowering stages, dried at $55^{\circ} \mathrm{C}$, ground, and analyzed for soluble carbohydrates (fructose + sucrose + glucose + pinitol) and starch. Approximately 20 genotypes having, respectively, the highest and lowest NSC concentrations were pooled to constitute 2 contrasted 1-kg forage samples. Samples of high- $(17.9 \% \mathrm{DM})$ and low- $(7.4 \% \mathrm{DM})$ NSC alfalfa were respectively allocated to separate dual-flow fermenters in a completely randomized design with 3 replications. Rumen inoculum was obtained from $4 \mathrm{ru}-$ minally fistulated cows in early lactation that were fed a TMR with a 50:50 forage to concentrate ratio. A 10-d incubation period was used, with the first $6 \mathrm{~d}$ serving as an adaptation period followed by $4 \mathrm{~d}$ of sampling with solid and liquid dilution rates in the fermenters set at approximately 2.0 and $4.3 \% / \mathrm{h}$, respectively. High versus low NSC concentration in alfalfa significantly enhanced the apparent digestibility of $\mathrm{OM}(59.1 \%$ for high-NSC alfalfa vs. $54.4 \%$ for low-NSC alfalfa) and DM (60.0 vs. $54.3 \%)$ and the true digestibility of DM (74.1 vs. $64.7 \%)$. Increasing NSC concentration in alfalfa (high vs. low) significantly decreased ruminal $\mathrm{pH}(6.85$
\end{abstract}

\footnotetext{
Received May 19, 2009.

Accepted October 29, 2009

${ }^{1}$ Contribution number 1029 from the Dairy and Swine Research and Development Centre, PO Box 90, STN-Lennoxville, Sherbrooke, Québec, Canada J1M $1 \mathrm{Z3}$

${ }^{2}$ Corresponding author: Robert.Berthiaume@agr.gc.ca
}

vs. 7.08 ) and $\mathrm{NH}_{3}-\mathrm{N}$ concentration (26.0 vs. $33.6 \mathrm{mg} /$ $\mathrm{dL}$ ) and increased total VFA concentration (94.9 vs. $83.0 \mathrm{mM}$ ). Molar proportions of acetate, isobutyrate, and isovalerate significantly decreased, whereas molar proportions of propionate and butyrate significantly increased with high-NSC alfalfa, resulting in a more glucogenic fermentation. More importantly, microbial $\mathrm{N}$ flow (263 vs. $230 \mathrm{mg} / \mathrm{d}$ ) and bacterial $\mathrm{N}$ efficiency (41.1 vs. $29.6 \%$ of available $\mathrm{N}$ ), measured using ${ }^{15} \mathrm{~N}$ as a microbial marker, both significantly increased with the high-NSC alfalfa. These results indicate that increasing the concentration of NSC in alfalfa promotes a glucogenic fermentation and enhances microbial $\mathrm{N}$ synthesis in the rumen.

Key words: dairy cow, nonstructural carbohydrate, microbial N, rumen fermentation

\section{INTRODUCTION}

Alfalfa (Medicago sativa L.) is the predominant forage species fed to dairy cows in North America. The concentration of soluble proteins in alfalfa is high and generally exceeds the capacity of rumen microbes to utilize N efficiently. Excess NPN is excreted via the urine, which may contribute to water and air pollution (NRC, 2001) and adversely affect the health and reproduction of the cow (McCormick et al., 1999). Van Soest (1994) suggested increasing water-soluble carbohydrates (WSC) and starch as an approach to improving alfalfa protein utilization by ruminants. Others (Johnson, 1976) proposed that the synchronized release of $\mathrm{N}$ and NSC (soluble carbohydrates + starch) in the rumen could maximize rumen capture of soluble N. However, recent research suggested that the ratio between soluble $\mathrm{N}$ and rumen-fermentable energy, coming mostly from NSC, is a much more important determinant of ruminal $\mathrm{N}$ losses than synchrony in the rates of $\mathrm{N}$ and energy release (Dewhurst et al., 2000; Huhtanen and Shingfield, 2005).

It is generally recognized that there is genetic variation in the type and concentrations of NSC in grasses 
(McDonald et al., 1991). In the UK, grass breeders have produced ryegrass cultivars (Humphreys, 1989) with greater WSC concentrations (high-sugar grasses). These cultivars have increased the efficiency of $\mathrm{N}$ use by zero-grazed dairy cows (Miller et al., 2001), the BW gain of grazing lambs (Lee et al., 2001), and the DMI (Lee et al., 2002b), microbial $\mathrm{N}$ flows to the duodenum (Lee et al., 2002b), and efficiency of microbial protein synthesis in beef cattle (Merry et al., 2006). In vitro studies (Lee et al., 2002a; 2003; Merry et al., 2006) have also helped to determine the effects of increasing the supply of WSC to the rumen microbial population under controlled conditions. Generally, an increase in WSC concentration in perennial ryegrass available to rumen microbes has been shown to increase the ruminal glucogenic:lipogenic VFA ratio and to reduce ruminal ammonia concentrations (Lee et al., 2002a; 2003; Merry et al., 2006). These findings indicate the potential for improved animal productivity of high-WSC forages. This improvement is likely mediated through an increase in the efficiency of $\mathrm{N}$ and energy utilization as a result of reduced ruminal ammonia concentrations and changes in the type of energy-yielding substrates (e.g., VFA) absorbed from the rumen associated with high-WSC forages.

However, to our knowledge, little research has been conducted to improve the NSC concentration in alfalfa through breeding and management practices or to document the effect of increasing NSC concentration on the efficiency of microbial synthesis in the rumen. In this study, we used the inherent genetic variability and differences between harvests to evaluate the effect of alfalfa forage with highly contrasting NSC concentration on in vitro ruminal function parameters and efficiency of microbial protein synthesis measured in a continuous culture system.

\section{MATERIALS AND METHODS}

\section{Plant Material}

More than 500 genotypes of the alfalfa cultivar AC Caribou grown as spaced plants in a field site near Québec City, Québec, Canada $\left(46^{\circ} 47^{\prime} \mathrm{N}, 71^{\circ} 07^{\prime} \mathrm{W}\right.$; elevation $=65 \mathrm{~m}$ ) were individually harvested on September 13,2004 at the late vegetative stage of development (Fick and Mueller, 1989). Within 15 min after cutting, forage samples were transferred to a large draft oven, dried at $55^{\circ} \mathrm{C}$, and subsequently ground using a Wiley mill (standard model 3; Arthur H. Thomas Co., Philadelphia, PA) fitted with a 1-mm screen. Each sample was scanned using a monochromator NIRS instrument (Foss NIRSystems 6500, Silver Spring, MD). A subset of 115 samples was chemically analyzed for soluble car- bohydrates (fructose + sucrose + glucose + pinitol) by HPLC (Brito et al., 2008) and for starch using a colorimetric method as described previously (Bertrand et al., 2003). Results from this subset were used to calibrate and validate an equation allowing the prediction of NSC concentration (soluble carbohydrates + starch) for all samples; the validation statistics were all acceptable $(\mathrm{n}=20 ; \mathrm{SD}=4.4 \% \mathrm{DM}$; standard error of prediction corrected for the bias $=0.45 \% \mathrm{DM} ; \mathrm{R}^{2}=0.99$ ). The 50 genotypes with superior NSC and the 50 genotypes with inferior NSC were identified and harvested again on July 28, 2005 at the flowering stage of development, dried, and chemically analyzed in duplicate as described previously. The average NSC concentration was $13.5 \% \mathrm{DM}$ in 2004 for the 50 genotypes with superior NSC and $8.4 \%$ DM in 2005 for the 50 genotypes with inferior NSC; we chose these 2 groups of genotypes to maximize the difference in NSC concentration. Ground material of genotypes having, respectively, the highest NSC concentrations in the 2004 harvest and the lowest NSC concentrations in the 2005 harvest was pooled to constitute 2 highly contrasting 1-kg samples. Among the 20 low-NSC genotypes that were pooled to constitute 1 of the 2 pooled samples, soluble carbohydrate concentration varied between 5.4 and $7.0 \%$ DM, starch concentration varied between 1.3 and $2.3 \% \mathrm{DM}$, and NSC concentration varied between 6.7 and $8.7 \%$ DM. Among the 23 high-NSC genotypes, soluble carbohydrate concentration varied between 9.5 and $12.8 \% \mathrm{DM}$, starch concentration varied between 5.1 and $10.4 \%$ DM, and NSC concentration varied between 15.5 and $23.0 \%$ DM. Subsequent chemical determination of carbohydrates in the 2 pooled samples confirmed their contrasted concentrations (17.9 vs. $7.4 \%$ DM for highand low-NSC alfalfa, respectively; Table 1).

\section{Experimental Design and Treatments}

The experiment was conducted as a completely randomized design with 2 dietary treatments and 3 replications per treatment. The experimental period lasted $10 \mathrm{~d}$, with the first $6 \mathrm{~d}$ serving as an adaptation period allowing equilibration of microbial populations followed by $4 \mathrm{~d}$ of sampling. The 2 experimental treatments were high- versus low-NSC alfalfa. The source of inoculum, feeding rate, and solid and liquid dilution rates were as described in Fraser et al. (2007).

\section{Source of Inoculum}

Mixed rumen contents were collected $2 \mathrm{~h}$ after the morning feeding from 4 ruminally fistulated, lactating Holstein dairy cows that were fed an early-lactation diet $(16.7 \% \mathrm{CP}, 34.4 \% \mathrm{NDF})$ consisting of $50 \%$ forage 
Table 1. Chemical composition of alfalfa with high and low concentrations of NSC administered to the continuous culture fermenters ${ }^{1}$

\begin{tabular}{lcc}
\hline Item \% of DM unless stated & High NSC & Low NSC \\
\hline DM, \% & $94.1 \pm 0.03^{1}$ & $93.9 \pm 0.02$ \\
OM & $90.6 \pm 0.07$ & $90.2 \pm 0.05$ \\
CP & $22.4 \pm 0.31$ & $28.1 \pm 0.18$ \\
NDF & $25.8 \pm 0.15$ & $28.7 \pm 0.34$ \\
ADF & $22.0 \pm 0.61$ & $24.0 \pm 0.42$ \\
Acid detergent lignin & $7.0 \pm 0.79$ & $6.3 \pm 0.45$ \\
Fructose & $0.41 \pm 0.019$ & $0.30 \pm 0.023$ \\
Sucrose & $8.48 \pm 0.095$ & $3.74 \pm 0.062$ \\
Glucose & $0.71 \pm 0.009$ & $0.51 \pm 0.098$ \\
Pinitol & $2.13 \pm 0.187$ & $1.75 \pm 0.103$ \\
Starch & $6.15 \pm 0.011$ & $1.07 \pm 0.008$ \\
NSC & $17.87 \pm 0.298$ & $7.37 \pm 0.158$ \\
\hline
\end{tabular}

${ }^{1}$ Values are means $\pm \mathrm{SD}$.

and $50 \%$ concentrate on a DM basis (Table 2). Mixed rumen contents for use in the fermenters were squeezed through 4 layers of cheesecloth into an insulated thermos. Prior to their utilization for the incubation, the pooled rumen contents were analyzed to determine the natural abundance of ${ }^{15} \mathrm{~N}$ (i.e., background concentration). All procedures with the cows were performed in accordance with the guidelines of the Canadian Council on Animal Care (CCAC, 1993).

\section{Continuous Culture System}

A 6-unit, dual effluent system similar to that described by Hoover et al. (1976) was used in this study. Each fermenter had a 1.3-L nominal capacity. At the beginning, $350 \mathrm{~mL}$ of warmed McDougall's buffer ( $\mathrm{pH}$ 8.2; McDougall, 1948) modified to contain $0.5 \mathrm{~g} / \mathrm{L}$ of $\left(\mathrm{NH}_{4}\right)_{2} \mathrm{SO}_{4}, 950 \mathrm{~mL}$ of strained rumen fluid, and $12 \mathrm{~g}$ of alfalfa (DM basis) were added to each fermenter. Thereafter, the fermenters were manually fed with $24 \mathrm{~g}$ (DM basis) of alfalfa per day, divided into 2 equal feedings at 0600 and 1800 h. Fermenters were maintained at a constant temperature of $39^{\circ} \mathrm{C}$ and were infused with a constant stream of $\mathrm{CO}_{2}$ at a rate of $20 \mathrm{~mL} / \mathrm{min}$ to maintain anaerobic conditions. Infusion of artificial saliva and flow of filtered liquid were set to maintain solid and liquid dilution rates of approximately 2.0 and $4.3 \% / \mathrm{h}$, respectively. Daily effluent was collected in a $4.0-\mathrm{L}$ container immersed in an ice water bath $\left(-4^{\circ} \mathrm{C}\right)$ to inhibit microbial growth.

\section{Measurements}

Alfalfa Digestibility. From d 7 to 10, daily effluent was homogenized and a $400-\mathrm{mL}$ subsample was taken and centrifuged $\left(20,000 \times g, 30 \mathrm{~min}, 4^{\circ} \mathrm{C}\right)$. The resulting supernatant was discarded and the solid fraction (indigestible portion + microbial fraction) was harvested and dried in a forced-air oven at $55^{\circ} \mathrm{C}$ for $48 \mathrm{~h}$ for the determination of DM, OM, NDF, ADF, and total N.

Fermentation End-Products. Fermenter $\mathrm{pH}$ was recorded at 2-h intervals daily using a $\mathrm{pH}$ meter (model 4505, Chemtrix Inc., Hillsboro, OR). On d 6 to 10, just before morning feeding, subsamples $(4.0 \mathrm{~mL})$ were taken from the fermenter liquid, preserved as described previously (Fraser et al., 2007), and stored at $-20^{\circ} \mathrm{C}$ until analyzed for $\mathrm{NH}_{3}$ and VFA concentrations.

Microbial Protein Synthesis. Microbial protein synthesis was estimated using ${ }^{15} \mathrm{~N}$ as a microbial marker. On d 1, McDougall's buffer solution was further modified by replacing the $\left(\mathrm{NH}_{4}\right)_{2} \mathrm{SO}_{4}$ with labeled $\left({ }^{15} \mathrm{NH}_{4}\right)_{2} \mathrm{SO}_{4}(0.5 \mathrm{~g} / \mathrm{L}$; Sigma Chemical Co., St. Louis, MO; minimum ${ }^{15} \mathrm{~N}$ enrichment $=10.01$ atom \%). From d 7 to 10 , the total effluents collected were weighed, homogenized, and subsampled. The first subsample was centrifuged $\left(20,000 \times g, 30 \mathrm{~min}, 4^{\circ} \mathrm{C}\right)$ to isolate residual (microbial + undigested feed) N (RN). A second subsample was centrifuged at low speed $(500 \times g, 10 \mathrm{~min}$, $4^{\circ} \mathrm{C}$ ) to remove feed particles. A $60-\mathrm{mL}$ sample of the supernatant was centrifuged $\left(20,000 \times g, 30 \mathrm{~min}, 4^{\circ} \mathrm{C}\right)$ to isolate microbial cells (MN). The resulting pellets ( $\mathrm{RN}$ and $\mathrm{MN}$ ) were washed using deionized water and centrifuged 3 times $\left(20,000 \times g, 30 \mathrm{~min}, 4^{\circ} \mathrm{C}\right)$, resuspended in distilled water, frozen at $-20^{\circ} \mathrm{C}$ until they were lyophilized, weighed for DM determination, and ground with a ball mill (Mixer Mill MM2000, Retsch, Haan, Germany) to a fine powder. Samples of RN and

Table 2. Ingredients, DM, and chemical composition of the earlylactation diet fed to ruminal contents donor cows

\begin{tabular}{lc}
\hline Item, \% of DM unless stated & Value \\
\hline Ingredient & \\
Barley silage & 30.6 \\
Alfalfa hay & 9.8 \\
Barley grain, steam-rolled & 47.5 \\
Corn gluten meal & 3.36 \\
Canola meal & 2.91 \\
Soybean meal & 2.91 \\
Beet molasses & 0.49 \\
Canola oil & 0.90 \\
Vitamin-mineral mix & 0.72 \\
Calcium carbonate & 0.67 \\
Dicalcium phosphorus & 0.36 \\
Monosodium phosphate & 0.04 \\
Binding agent & 0.15 \\
DM and chemical composition & \\
DM & 39.0 \\
OM & 92.7 \\
CP & 16.3 \\
NDF & 33.5 \\
ADF & 18.6 \\
Acid detergent lignin, \% of NDF & 12.9 \\
Starch & 45.5 \\
NE, Mcal/kg & 1.60 \\
\hline
\end{tabular}

${ }^{1}$ Aka, Bear River Zeolite of Canada Corp., Lethbridge, Alberta, Canada. 
MN pellets were pooled across sampling days and analyzed for total $\mathrm{N}$ and ${ }^{15} \mathrm{~N}$ concentrations.

\section{Chemical Analyses}

Analytical DM concentration of the diets and effluent feed residue from the fermenters were determined by drying at $135^{\circ} \mathrm{C}$ for $2 \mathrm{~h}$ (AOAC, 1990). Ash concentration was determined by combustion at $550^{\circ} \mathrm{C}$ overnight, and $\mathrm{OM}$ was subsequently calculated as 100 minus the percentage of ash (AOAC, 1990). The NDF and ADF concentrations were determined according to Van Soest et al. (1991). Heat-stable $\alpha$-amylase and sodium sulfite were used in the NDF procedure. Acid detergent lignin was determined as outlined in AOAC (1990; method 973.18). Total concentration in alfalfa samples, effluent feed residues, and undigested feed residues were determined by dry combustion (Model NA 1500, Carlo Erba Instruments, Rodano, MI, Italy). Crude protein was calculated as $\mathrm{N} \times 6.25$.

Concentration of VFA was determined by GLC (Hewlett Packard Model 5890, Agilent Technologies, Santa Clara, CA) equipped with a 30-m (0.32-mm i.d.) Zebron FFAP column (Phenomenex, Florence, CA). The concentration of $\mathrm{NH}_{3}-\mathrm{N}$ was determined using the phenol-hypochlorite procedure (Weatherburn, 1967) adapted for a Technicon Autoanalyzer II. Total N and ${ }^{15} \mathrm{~N}$ concentrations of $\mathrm{RN}$ and $\mathrm{MN}$ were determined by flash combustion using a Model NA 1500 nitrogen analyzer (Carlo Erba Instruments, Rodano, Milan, Italy) and isotope ratio mass spectrometry (VG Isotech, Middlewich, UK), respectively.

\section{Calculations}

Yield of MN (milligrams/day) was estimated using the equation

$$
\mathrm{MN}=(\mathrm{APE} \text { in } \mathrm{RN} / \mathrm{APE} \text { in } \mathrm{MN}) \times \mathrm{RN},
$$

where APE (atom percent excess) in RN is the percentage excess of ${ }^{15} \mathrm{~N}$ in the microbial plus undigested feed residue, APE in MN is the percentage excess of ${ }^{15} \mathrm{~N}$ in the microbial fraction of the effluent, and $\mathrm{RN}$ is the total $\mathrm{N}$ in the microbial plus undigested feed residue (milligrams; Wang et al., 2000).

\section{Statistical Analyses}

Data were analyzed as repeated measures using the MIXED procedure of SAS (SAS Institute, 2006). Means were compared using the least squares means linear hypothesis test with treatments (high- vs. low-NSC alfalfa), days of sampling, and their interaction included as fixed effects, and fermenter nested within (treatment $\times$ day of sampling) as a random effect. Significance was declared at $P<0.05$.

\section{RESULTS AND DISCUSSION}

\section{Chemical Composition of Alfalfa}

The high- and low-NSC alfalfa had NSC concentrations of 17.9 and $7.4 \%$, NDF concentrations of 40.1 and $41.6 \%$, and CP concentrations of 22.4 and $28.1 \%$ of DM, respectively (Table 1). Concentrations of all measured NSC (fructose, sucrose, glucose, pinitol, and starch) were higher in high- than in low-NSC alfalfa. Concentrations of starch (6.2 vs. $1.1 \%$ of DM) and sucrose (8.5 vs. $3.7 \%$ of DM) contributed the most to the differences in NSC concentration between high- and low-NSC alfalfa, respectively. Such changes could be nutritionally beneficial to ruminants; it was previously shown that supplementation of forage grasses with starch (Bach et al., 1999) or an 80:20 inulin:sucrose solution (Lee et al., 2003) reduced $\mathrm{NH}_{3}-\mathrm{N}$ concentration in the $\mathrm{ru}-$ men. Increased concentrations of soluble carbohydrates and starch in high- versus low-NSC alfalfa were associated with lower concentrations of NDF, ADF, and CP. Burns et al. (2007) reported that the accumulation of NSC in alfalfa cut at sundown was generally associated with a reduction in the concentrations of NDF and its constituent fiber fractions, whereas Humphreys (1989) reported a negative genetic correlation between WSC and $\mathrm{CP}$ in perennial ryegrass. Our study highlights the extent of the variability of NSC concentration in alfalfa because of its inherent genetic variability and differences between harvests; the latter can be partly related to an effect of the stage of development. The innovative approach of pooling genotypes from both ends, in terms of NSC concentration, of an alfalfa population allowed us to show the potential benefits that could result from breeding or management practices used to increase NSC concentration in forage legumes.

\section{Nutrient Digestion}

Apparent digestibility of DM and OM and true digestibility of DM were greater $(P<0.05)$ in the high- than in the low-NSC alfalfa, whereas apparent digestibility of NDF and ADF was numerically higher but not significantly different (Table 3). Values for ADF and NDF apparent digestibility observed in the present study are similar to those reported by Orozco-Hernandez et al. (1997) in alfalfa harvested at the same stage of development. We have recently published the results of an in vivo study showing that, in baleage made from the same alfalfa cultivar harvested at sundown compared 
Table 3. Effects of high and low concentrations of NSC in alfalfa (treatment) and sampling day on digestibility of DM, OM, and fiber in the dual-flow continuous culture system

\begin{tabular}{|c|c|c|c|c|c|c|}
\hline \multirow[b]{2}{*}{ Item } & \multicolumn{2}{|c|}{ Treatment } & \multirow[b]{2}{*}{$\mathrm{SED}^{1}$} & \multicolumn{3}{|c|}{$P$-value } \\
\hline & High NSC & Low NSC & & Treatment & Sampling day & - Treatment $\times$ day \\
\hline \multicolumn{7}{|l|}{ True digestibility, $\%$} \\
\hline $\mathrm{DM}$ & 74.1 & 64.7 & 2.09 & 0.002 & 0.89 & 0.82 \\
\hline \multicolumn{7}{|l|}{ Apparent digestibility, \% } \\
\hline DM & 60.0 & 54.3 & 2.08 & 0.02 & 0.79 & 0.99 \\
\hline $\mathrm{OM}$ & 59.1 & 54.4 & 1.99 & 0.04 & 0.77 & 0.99 \\
\hline NDF & 58.5 & 56.3 & 2.58 & 0.42 & 0.91 & 0.99 \\
\hline $\mathrm{ADF}$ & 54.8 & 52.1 & 3.40 & 0.47 & 0.83 & 0.98 \\
\hline
\end{tabular}

${ }^{1} \mathrm{SED}=$ standard error of the differences of means.

with sunup, the apparent digestibility of $\mathrm{OM}$ in the sundown-cut alfalfa increased concomitantly to an increase of 2.3 percentage units in NSC concentration (Brito et al., 2008). Our results, both in vitro and in vivo, confirm that an increase in NSC concentration of at least 2.3 percentage units improves alfalfa DM digestibility, mostly through a reduction in NDF concentration. Similar to our previous in vivo findings (Brito et al., 2008), ruminal digestion of NSC was deemed almost complete in the conditions of the present study.

\section{Ruminal Environment}

As a consequence of the increased DM digestibility (Table 3), ruminal total VFA concentration was higher $(P=0.04)$ and ruminal $\mathrm{pH}$ was lower $(P=0.02)$ for the high- than for the low-NSC alfalfa (Table 4). Molar proportions of acetate, isobutyrate, and isovalerate were lower $(P \leq 0.007)$ for the high- compared with the lowNSC alfalfa, whereas the proportions of propionate and butyrate were higher $(P \leq 0.006)$. Consequently, the acetate:propionate ratio was lower for the high-NSC alfalfa. Bach et al. (1999) reported that supplementing a lush pasture with cracked corn, a source of starch, resulted in higher molar proportions of propionate, butyrate, and branched-chain VFA, lower molar proportions of acetate, and a lower acetate:propionate ratio. The increased proportion of butyrate is consistent with the results presented by Lee et al. (2002b) for steers offered perennial ryegrass selected for higher WSC concentration. Water-soluble carbohydrates have been shown to increase either acetate or butyrate (Huhtanen, 1998). Although the reasons for different fermentation patterns of WSC are not clear, it may be related to methane production because methanogenesis is a prerequisite to acetate but not to butyrate (Demeyer and Van Nevel, 1975). Branched-chain VFA (isobutyrate and isovalerate) are derived primarily from dietary proteins (Gorosito et al., 1985). Therefore, the lower CP concentration of the high-NSC alfalfa might explain why isobutyrate and isovalerate molar proportions were reduced. Ribeiro et al. (2005) also showed that branched-chain VFA molar proportions linearly decreased with the addition of sucrose to alfalfa hay and concluded that changes in branched-chain VFA were related to the decrease in $\mathrm{N}$ digestibility associated with sucrose addition. We reported the same phenomenon (Berthiaume et al., 2006) in an in vitro study comparing alfalfa harvested after 0 versus $12 \mathrm{~h}$ of daylight. However, we observed an increase in $\mathrm{N}$ truly digested in the rumen when cows were fed alfalfa mowed at sundown compared with alfalfa mowed at sunup (Brito et al., 2009). This apparent discrepancy may have to do with the longer wilting time associated with sundown cutting and harvesting. Papadopoulos and McKersie (1983) showed that wilted alfalfa suffered less proteolysis.

\section{N Metabolism}

Concentration of $\mathrm{NH}_{3}-\mathrm{N}(P=0.02)$ in the daily effluent was lower with high- compared with low-NSC alfalfa (Table 4). Considering the greater $\mathrm{N}$ intake with the low-NSC alfalfa $(987 \mathrm{mg} / \mathrm{d})$ than the high-NSC alfalfa $(795 \mathrm{mg} / \mathrm{d})$ as a result of the unexpectedly large difference in $\mathrm{CP}$ concentration between the 2 treatments (28.1 and 22.4\% DM for low- and high-NSC alfalfa, respectively), all the $\mathrm{N}$ flow data were reported relative to $\mathrm{N}$ ingested. True $\mathrm{N}$ flow, as a proportion of $\mathrm{N}$ input (dietary + infused), increased $(P=0.007)$ with the high- compared with the low-NSC alfalfa (Table $5)$. More importantly, the MN flow increased $(P<$ 0.001) with the high-NSC alfalfa, supporting our hypothesis that high NSC concentration in alfalfa would increase microbial protein synthesis. Brito et al. (2009) also observed an increase in microbial NAN flow at 
Table 4. Effect of high and low concentrations of NSC in alfalfa (treatment) and sampling day on ruminal pH and concentrations of VFA and ammonia measured in the dual-flow continuous culture system

\begin{tabular}{|c|c|c|c|c|c|c|}
\hline \multirow[b]{2}{*}{ Item } & \multicolumn{2}{|c|}{ Treatment } & \multirow[b]{2}{*}{$\mathrm{SED}^{1}$} & \multicolumn{3}{|c|}{$P$-value } \\
\hline & High NSC & Low NSC & & Treatment & Sampling day & Treatment $\times$ day \\
\hline Ruminal pH & 6.85 & 7.08 & 0.057 & 0.02 & 0.26 & 0.90 \\
\hline Total VFA, mmol/L & 94.9 & 83.0 & 5.13 & 0.04 & 0.04 & 0.72 \\
\hline \multicolumn{7}{|l|}{ VFA, mol/100 mol } \\
\hline Acetate & 61.4 & 65.2 & 1.24 & 0.007 & 0.27 & 0.91 \\
\hline Propionate & 20.3 & 18.4 & 0.57 & 0.006 & 0.52 & 0.98 \\
\hline Butyrate & 11.6 & 9.0 & 0.55 & 0.002 & 0.58 & 0.88 \\
\hline Isobutyrate & 1.6 & 1.9 & 0.06 & $<0.001$ & 0.81 & 0.59 \\
\hline Valerate & 2.7 & 2.4 & 0.17 & 0.23 & 0.30 & 0.92 \\
\hline Isovalerate & 2.0 & 2.6 & 0.14 & $<0.001$ & 0.25 & 0.86 \\
\hline Caproate & 0.5 & 0.5 & 0.06 & 0.60 & 0.37 & 0.99 \\
\hline Acetate:propionate & 3.03 & 3.59 & 0.167 & 0.006 & 0.41 & 0.97 \\
\hline $\mathrm{NH}_{3}-\mathrm{N}, \mathrm{mg} / \mathrm{L}$ & 260 & 336 & 25.0 & 0.02 & 0.76 & 0.94 \\
\hline
\end{tabular}

${ }^{1} \mathrm{SED}=$ standard error of the differences of means.

the omasum in alfalfa cut at sundown compared with that cut at sunup. Interestingly, supplementation of lush pasture with starch (Bach et al., 1999) increased bacterial $\mathrm{N}$ flow, as observed in the present study (Table 5), whereas infusion with incremental doses of an inulin:sucrose mixture (Lee et al., 2003) decreased bacterial $\mathrm{N}$ flow measured in vitro, suggesting that the type of carbohydrate provided is important. The current treatments had no effect on the flow of $\mathrm{N}$ from dietary origin expressed as a percentage of $\mathrm{N}$ input $(27.8$ and $28.0 \%$ for high- and low-NSC alfalfa, respectively; Table 5). This suggests that the reported increases in $\mathrm{DM}$ and $\mathrm{OM}$ digestibilities are the result of an increase in the concentration of the NSC fraction that is deemed completely digested.

\section{Microbial Efficiency}

The efficiency of microbial protein synthesis (expressed as grams of bacterial-N per kilogram of OM apparently digested in the rumen) was not affected by treatments (Table 5). Higher bacterial efficiencies have sometimes been associated with both higher (Hussein et al., 1991) and lower (Bach et al., 1999) bacterial yields. The ultimate goal of ruminant nutrition should be to maximize microbial growth and the amount of RDP that is captured into rumen microbial cells, not only to improve the supply of AA to the small intestine but also to decrease $\mathrm{N}$ losses. Therefore, Bach et al. (2005) suggested that efficiency of microbial protein synthesis is not a good estimator of the efficiency of available $\mathrm{N}$

Table 5. Effects of high and low concentrations of NSC in alfalfa (treatment) and sampling day on N degradation and efficiency of microbial protein synthesis in the dual-flow continuous culture system

\begin{tabular}{|c|c|c|c|c|c|c|}
\hline \multirow[b]{2}{*}{ Item } & \multicolumn{2}{|c|}{ Treatment } & \multirow[b]{2}{*}{$\mathrm{SED}^{1}$} & \multicolumn{3}{|c|}{$P$-value } \\
\hline & High NSC & Low NSC & & Treatment & Sampling day & Treatment $\times$ day \\
\hline Dietary N, mg/d & 795 & 987 & & & & \\
\hline $\mathrm{N}$ infused, mg/d & 91 & 95 & & & & \\
\hline \multicolumn{7}{|l|}{$\mathrm{N}$ flow, mg/d } \\
\hline Total & 737 & 831 & 30.8 & 0.02 & 0.56 & 0.95 \\
\hline Ammonia & 226 & 299 & 20.4 & 0.01 & 0.68 & 0.90 \\
\hline True & 510 & 532 & 24.0 & 0.38 & 0.73 & 0.99 \\
\hline Microbial & 263 & 230 & 9.5 & 0.005 & 0.49 & 0.97 \\
\hline Dietary & 247 & 302 & 15.4 & 0.005 & 0.89 & 0.98 \\
\hline \multicolumn{7}{|l|}{$\mathrm{N}$ flow, \% of $\mathrm{N}$ input } \\
\hline True & 57.5 & 49.2 & 2.42 & 0.007 & 0.73 & 0.99 \\
\hline Microbial & 29.7 & 21.3 & 0.95 & $<0.001$ & 0.45 & 0.93 \\
\hline Dietary & 27.8 & 28.0 & 1.56 & 0.94 & 0.91 & 0.99 \\
\hline EMPS $^{2}$ & 22.6 & 21.6 & 1.65 & 0.57 & 0.63 & 0.99 \\
\hline Bacterial-N/feed N, \% & 33.1 & 23.3 & 1.10 & $<0.001$ & 0.50 & 0.94 \\
\hline Bacterial-N/available $\mathrm{N},{ }^{3} \%$ & 41.1 & 29.6 & 2.19 & 0.007 & 0.68 & 0.98 \\
\hline
\end{tabular}

${ }^{1} \mathrm{SED}=$ standard error of the differences of means.

${ }^{2}$ EMPS $=$ efficiency of microbial protein synthesis (grams of bacterial-N per kilogram of OM apparently digested in the rumen).

${ }^{3} \mathrm{~N}$ intake - undegraded-N (Bach et al., 1999). 
capture by the rumen microbes. They proposed calculating the efficiency of $\mathrm{N}$ use by ruminal microbes as grams of bacterial $\mathrm{N}$ per gram of available $\mathrm{N}$, where available $\mathrm{N}$ is calculated as $\mathrm{N}$ input (dietary + artificial saliva) minus undegraded $\mathrm{N}$. Using this expression of efficiency, high-NSC alfalfa resulted in a greater $(P=$ 0.007 ) efficiency of $\mathrm{N}$ utilization by bacteria. This is consistent with the lower accumulation of $\mathrm{NH}_{3}-\mathrm{N}$ in the rumen with high- compared with low-NSC alfalfa. When expressed as grams of bacterial $\mathrm{N}$ per 100 grams of feed $\mathrm{N}$, the $\mathrm{N}$ in high-NSC alfalfa was utilized more efficiently by rumen bacteria $(P<0.001)$ than the $\mathrm{N}$ in the low-NSC alfalfa. However, even with the high-NSC alfalfa, $\mathrm{N}$ use efficiency reported in the present study (33.1\%) was similar to that reported by Bach et al. (1999) with a grass-legume pasture diet (32.8\%) but lower than that reported by others (Merry et al., 2006) with red clover $(54 \%)$.

\section{CONCLUSIONS}

Using the inherent genetic variability and differences between harvests, we observed that a group of alfalfa genotypes with a high NSC concentration (17.9\% DM for high-NSC alfalfa vs. 7.4\% DM for low-NSC alfalfa) was more digestible and resulted in a decrease in ruminal $\mathrm{pH}$, an increase in total ruminal VFA concentration, and a shift toward a more glucogenic fermentation in an in vitro continuous culture system. The observed reduction in rumen ammonia and improvements in MN flow (263 vs. $230 \mathrm{mg} / \mathrm{d}$ ) and bacterial utilization of available N (41.1 vs. 29.6\%) with high versus low NSC alfalfa confirm the possibility of improving the supply of microbial $\mathrm{N}$ to the small intestine and of decreasing $\mathrm{N}$ losses in forage-fed ruminants by feeding alfalfa with a high NSC concentration. Our in vitro study provides evidence that increased NSC concentration in alfalfa enhances MN synthesis in the rumen, but in vivo studies are needed to confirm these results with dairy cows fed at greater feeding and passage rates.

\section{REFERENCES}

AOAC. 1990. Official Methods of Analysis. Vol. 1. 15th ed. Association of Official Analytical Chemists, Arlington, VA.

Bach, A., S. Calsamiglia, and M. D. Stern. 2005. Nitrogen metabolism in the rumen. J. Dairy Sci. 88(E-Suppl.):E9-E21.

Bach, A., I. K. Koon, M. D. Stern, H. G. Jung, and H. ChesterJones. 1999. Effects of type of carbohydrate supplementation to lush pasture on microbial fermentation in continuous culture. J. Dairy Sci. 82:153-160.

Berthiaume, R., G. Tremblay, Y. Castonguay, A. Bertrand, G. Bélanger, C. Lafrenière, and R. Michaud. 2006. Length of the daylight period before cutting improves rumen fermentation of alfalfa assessed by in vitro gas production. J. Dairy Sci. 89(Suppl.1):102. (Abstr.)

Bertrand, A., Y. Castonguay, P. Nadeau, S. Laberge, R. Michaud, G. Bélanger, and P. Rochette. 2003. Oxygen deficiency affects carbohydrate reserves in overwintering forage crops. J. Exp. Bot. 54:1721-1730.

Brito, A. F., G. F. Tremblay, H. Lapierre, A. Bertrand, Y. Castonguay, G. Bélanger, R. Michaud, C. Benchaar, D. R. Ouellet, and R. Berthiaume. 2009. Alfalfa cut at sundown increases bacterial protein synthesis in late-lactation dairy cows. J. Dairy Sci. 92:1092-1107.

Brito, A. F., G. F. Tremblay, D. R. Ouellet, A. Bertrand, Y. Castonguay, G. Bélanger, R. Michaud, H. Lapierre, and R. Berthiaume. 2008. Alfalfa cut at sundown and harvested as baleage improves milk yield of late-lactation dairy cows. J. Dairy Sci. 91:3968-3982.

Burns, J. C., D. S. Fisher, and H. F. Mayland. 2007. Diurnal shifts in nutritive value of alfalfa harvested as hay and evaluated by animal intake and digestion. Crop Sci. 47:2190-2197.

Canadian Council on Animal Care. 1993. Guide to the Care and Use of Experimental Animals. Vol. 1. 2nd ed. E. D. Olfert, B. M. Cross, and A. A. McWilliam, ed. Canadian Council on Animal Care, Ottawa, Ontario, Canada.

Demeyer, D. I., and C. J. Van Nevel. 1975. Methanogenesis, an integrated part of carbohydrate fermentation and its control. Pages 366-382 in Digestion and Metabolism in the Ruminant. I. W. MacDonald and A. C. I. Warner, ed. University of New England Publishing Unit, Armidale, Australia.

Dewhurst, R. J., D. R. Davies, and R. J. Merry. 2000. Microbial protein supply from the rumen. Anim. Feed Sci. Technol. 85:1-21.

Fick, G. W., and S. C. Mueller. 1989. Alfalfa: Quality, maturity, and mean stage of development. Information bulletin 217. Cornell Cooperative Extension Cornell University, Ithaca, NY

Fraser, G. R., A. V. Chaves, Y. Wang, T. A. McAllister, K. A. Beauchemin, and C. Benchaar. 2007. Assessment of the effects of cinnamon leaf oil on rumen microbial fermentation using two continuous culture systems. J. Dairy Sci. 90:2315-2328.

Gorosito, A. R., J. B. Russell, and P. J. Van Soest. 1985. Effect of carbon- 4 and carbon- 5 volatile fatty acids on digestion of plant cell wall in vitro. J. Dairy Sci. 68:840-847.

Hoover, W. H., B. A. Crooker, and C. J. Sniffen. 1976. Effects of differential solid-liquid removal rates on protozoa numbers in continuous cultures of rumen contents. J. Anim. Sci. 43:528534.

Huhtanen, P. 1998. Supply of nutrients and productive responses in dairy cows given diets based on restrictively fermented silage. Agric. and Food Sci. in Finland. 7:219-250.

Huhtanen, P., and K. J. Shingfield. 2005. Grass silage: Factors affecting efficiency of $\mathrm{N}$ utilization in milk production. Pages 35-50 in Silage Production and Utilization. Proceedings of the XIVth International Silage Conference, Belfast, Northern Ireland. Wageningen Academic Publishers, Wageningen, the Netherlands.

Humphreys, M. O. 1989. Water-soluble carbohydrates in perennial ryegrass breeding, 111. Relationships with herbage production, digestibility and crude protein content. Grass Forage Sci. 44:423430.

Hussein, H. S., R. M. Jordan, and M. D. Stern. 1991. Ruminal protein metabolism and intestinal amino acid utilization as affected by dietary protein and carbohydrate sources in sheep. J. Anim. Sci. 69:2134-2146.

Johnson, R. R. 1976. Influence of carbohydrate solubility on non-protein nitrogen utilization in the ruminant. J. Anim. Sci. 43:184-191.

Lee, M. R. F., A. E. Brooks, J. M. Moorby, M. O. Humphreys, M. K. Theodorou, J. C. MacRae, and N. D. Scollan. 2002a. In vitro investigation into the nutritive value of Lolium perenne bred for an elevated concentration of water-soluble carbohydrate and the added effect of sample processing: Freeze-dried and ground vs. frozen and thawed. Anim. Res. 51:269-277.

Lee, M. R. F., L. J. Harris, J. M. Moorby, M. O. Humphreys, M. K. Theodorou, J. C. MacRae, and N. D. Scollan. 2002b. Rumen metabolism and nitrogen flow to the small intestine in steers offered Lolium perenne containing different levels of water-soluble carbohydrate. Anim. Sci. 74:587-596.

Lee, M. R. F., E. L. Jones, M. O. Humphreys, J. M. Moorby, M. K. Theodorou, J. C. MacRae, and N. D. Scollan. 2001. Production responses from lambs grazed on Lolium perenne selected for an 
elevated water-soluble carbohydrate concentration. Anim. Res. 50:441-449.

Lee, M. R. F., R. J. Merry, D. R. Davies, J. M. Moorby, M. O. Humphreys, M. K. Theodorou, J. C. MacRae, and N. D. Scollan. 2003. Effect of increasing availability of water-soluble carbohydrates on in vitro rumen fermentation. Anim. Feed Sci. Technol. 104:59-70.

McCormick, M. E., D. D. French, T. F. Brown, G. J. Cuomo, A. M. Chapa, J. M. Fernandez, J. F. Beatty, and D. C. Blouin. 1999. Crude protein and rumen undegradable protein effects on reproduction and lactation performance of Holstein cows. J. Dairy Sci. 82:2697-2708.

McDonald, P., A. R. Henderson, and S. J. E. Heron. 1991. The Biochemistry of Silage. 2nd ed. Chalcombe Publications, Marlow, UK.

McDougall, E. I. 1948. Studies on ruminant saliva 1. The composition and output of sheep's saliva. Biochem. J. 43:99-109.

Merry, R. J., M. R. F. Lee, D. R. Davies, R. J. Dewhurst, J. M. Moorby, N. D. Scollan, and M. K. Theodorou. 2006. Effects of high-sugar ryegrass silage and mixtures with red clover silage on ruminant digestion. 1 . In vitro and in vivo studies of nitrogen utilization. J. Anim. Sci. 84:3049-3060.

Miller, L. A., J. M. Moorby, D. R. Davies, M. O. Humphreys, N. D. Scollan, J. C. MacRae, and M. K. Theodorou. 2001. Increased concentration of water-soluble carbohydrate in perennial ryegrass (Lolium perenne L.): Milk production from late-lactation dairy cows. Grass Forage Sci. 56:383-394.
National Research Council. 2001. Nutrient Requirements of Dairy Cattle. 7th rev. ed. Natl. Acad. Sci., Washington, DC.

Orozco-Hernandez, J. R., G. J. Brisson, and V. Girard. 1997. Timothy grass or alfalfa silage for cows in midlactation: Effect of supplementary barley. J. Dairy Sci. 80:2876-2884.

Papadopoulos, Y. A., and B. D. McKersie. 1983. A comparison of protein degradation during wilting and ensiling of six forage species. Can. J. Plant Sci. 63:903-912.

Ribeiro, C. V. D. M., S. K. R. Karnati, and M. L. Eastridge. 2005. Biohydrogenation of fatty acids and digestibility of fresh alfalfa or alfalfa hay plus sucrose in continuous culture. J. Dairy Sci. 88:4007-4017.

SAS Institute. 2006. SAS OnlineDoc 9.1.3. SAS Institute Inc., Cary, $\mathrm{NC}$.

Van Soest, P. J. 1994. Nutritional Ecology of the Ruminant. 2nd ed. Cornell University Press, Ithaca, NY.

Van Soest, P. J., J. B. Robertson, and B. A. Lewis. 1991. Methods for dietary fiber, neutral detergent fiber, and nonstarch polysaccharides in relation to animal nutrition. J. Dairy Sci. 74:3583-3597.

Wang, Y., T. A. McAllister, L. J. Yanke, Z. J. Xu, P. R. Cheeke, and K.-J. Cheng. 2000. In vitro effects of steroidal saponins from yucca schidigera extract on rumen microbial protein synthesis and ruminal fermentation. J. Sci. Food Agric. 80:2114-2122.

Weatherburn, M. W. 1967. Phenol-hypochlorite reaction for determination of ammonia. Anal. Chem. 39:971-974. 